\title{
Peripheral university region and knowledge- based development: the case of Joensuu
}

ARTICLE in INTERNATIONAL JOURNAL OF KNOWLEDGE-BASED DEVELOPMENT · JANUARY 2012

DOI: 10.1504/IJKBD.2012.048380

1 AUTHOR:

Teemu Makkonen

University of Surrey

21 PUBLICATIONS 17 CITATIONS

SEE PROFILE 


\title{
Peripheral university region and knowledge-based development: the case of Joensuu
}

\section{Teemu Makkonen}

Department of Geosciences and Geography,

University of Helsinki, P.O. BOX 64, FI-00014 University of Helsinki, Finland

E-mail: teemu.makkonen@helsinki.fi

\begin{abstract}
Universities have gained an increasing amount of attention in the literature as drivers of knowledge-based development. Still, the mere presence of a university alone is not sufficient: the mechanisms of how knowledge is transferred from universities to industry are an important factor affecting the successfulness of the universities' participation in the development of the local economy. The different mechanisms of knowledge transfer are under review here in the context of a peripheral town, Joensuu, in eastern Finland. In relation to the knowledge transfer mechanisms in the region a lack of entrepreneurial spirit of graduates and faculty and a partial mismatch between regional business life needs and university research was reported. This paper discusses how to alleviate these lacks and mismatches. Interviews conducted for the study also reveal that the peripheral location of Joensuu poses some restrictions on the availability of skilled workers, but this is compensated by employee loyalty to their employers.
\end{abstract}

Keywords: Finland, knowledge-based development, knowledge transfer, peripheral regions, regional innovation systems, university-industry collaboration

Biographical note: Teemu Makkonen is currently a PhD student at the department of Geosciences and Geography, University of Helsinki. He is currently pursuing his Doctorate degree in the area of economic geography.

This is an Accepted Manuscript of an article published by Inderscience in International Journal of Knowledge-Based Development on August 06, 2012, Vol. 3 , No. 3, pp. 216-233. Available online: http://dx.doi.org/10.1504/IJKBD.2012.048380 


\section{Introduction}

In brief, knowledge-based development (KBD) is most often regarded as economic growth in a community resulting from technologically and educationally based productivity (Carrillo, 2009). In this respect the role of universities has increasingly gained attention in the literature on spatial development, competitiveness and innovative capabilities of regions, because universities are important producers of the most fundamental resource of the modern economy - knowledge (see Lundvall, 1992). The task is no longer to vindicate the industrial value of academic research, but to find the most effective mechanisms for their transfer to industry (Niosi, 2006). In fact, the interplay between universities, knowledge and spatial development is seen to be so engrossing that a recent theme issue on the International Journal of KnowledgeBased Development was dedicated to papers discussing the subject (see Franz, 2011). The question of university-industry (U-I) collaboration is topical especially in Finland, where universities have recently gone through a renovation that increased the economic autonomy of the universities by government-imposed incentives to acquire private sector funding.

The discussion of universities' role as part of local development has usually been, with a few refreshing exceptions (see Benneworth, 2007; Benneworth and Charles, 2005), more often concentrated on well-off regions or well-known universities (e.g. Bathelt and Spigel, 2011; Bramwell and Wolfe, 2008). Therefore, Joensuu offers an interesting case location for the attempt to fill in this gap, as an example of a peripheral, less-known university region. The selection of Joensuu as a case study location was also motivated by the profoundly different research and development (R\&D) profile of Joensuu compared to the national average of Finland: in Joensuu the 
bulk of R\&D related functions are carried out by the public sector (most of it from the university sector). Furthermore, previous qualitative empirical works related to KBD in Finland have typically focused on the larger city-regions and especially on the Helsinki Metropolitan Area (cf. Sotarauta and Kosonen, 2004).

These preliminary notions lead to the main theme of this paper, which is to evaluate the role of the U-I collaboration [the main emphasis is on the knowledge transfer mechanisms of the university (see Bercovitz and Feldman, 2006)] in supporting KBD in the regional context of Joensuu; that is, can the regional innovation system of Joensuu be regarded as university driven (cf. Doloreux and Dionne, 2008)? To answer this question, first, the case location is briefly described. The tentative picture drawn is then deepened with semi-structured thematic interviews and analysis (see Aronson, 1994). The attempt to derive arguments that are not evident in quantitative terms and, the notion by Schiuma and Lerro (2010), that there is a need for better understanding on how the knowledge-based factors are affecting innovation performance and regional development act as the motives behind this approach. The main stakeholders interviewed were chosen, according to the framework of regional innovation systems, from both public and private organizations, including the university [University of Eastern Finland (UEF), Campus of Joensuu (UEF has campuses also in Kuopio and Savonlinna)], regional intermediaries, business and governmental and administrative organisations and the most notable 'local' businesses (Appendix 1).

\section{Background}

The concept of innovation systems is frequently utilised as the basis for regional comparisons of $\mathrm{KBD}$ characteristics and for defining the actors taking part in 
knowledge production and application. In a regional innovation system (RIS) the main groups of actors that usually contribute to the innovative activities of a region are firms, public research institutions and universities, supportive services and the workforce of the region (see Asheim and Gertler, 2005; Cooke, 1992); for a critical perspective on RIS see Doloreux and Parto (2005). As spatial scales are intertwined, the national policy instruments as well as growing interregional cooperation and globalization make their own contribution to RIS (Ahlqvist and Inkinen, 2007). For example in Finland, regional KBD policy initiatives have been supported both by national programmes and by the EU Structural Funds (Mukkala, 2010).

The notion of knowledge as a driving force behind the development is a fundamental part of the innovation system: a schematic illustration of the structure of RIS is represented in figure 1, in which RIS is divided into two subsystems embedded in a common regional socio-economic and cultural setting. The knowledge generation and diffusion subsystem (public sector) is where knowledge is mainly generated and the point from which it travels to the knowledge application and exploitation subsystem (private sector), where knowledge is primarily transformed into innovation.

The main interest here is in the interaction and knowledge transfer between these two subsystems: although firms play a crucial role, the overall innovation capacity of a region is not dependent only on firms' innovation performance (e.g. Asheim and Coenen, 2005). As Parrilli et al. [(2010), p.367] have stressed, innovation promotion needs to be based on 'critical masses' of firms, but at the same time firms need 'innovation infrastructures and institutions', as, at least, small firms in isolation usually lack the resources to invest in $\mathrm{R} \& \mathrm{D}$ and other innovation activities, necessary 
for innovation creation, by themselves [see also Etzkowitz and Leydesdorff (2000) for the Triple Helix model of university-industry-government relations]. Thus it has been posited that in a regional context well-functioning mechanisms of knowledge transfer between these two subsystems leads to a better innovation performance and ultimately to economic growth (see Bercovitz and Feldman, 2006).

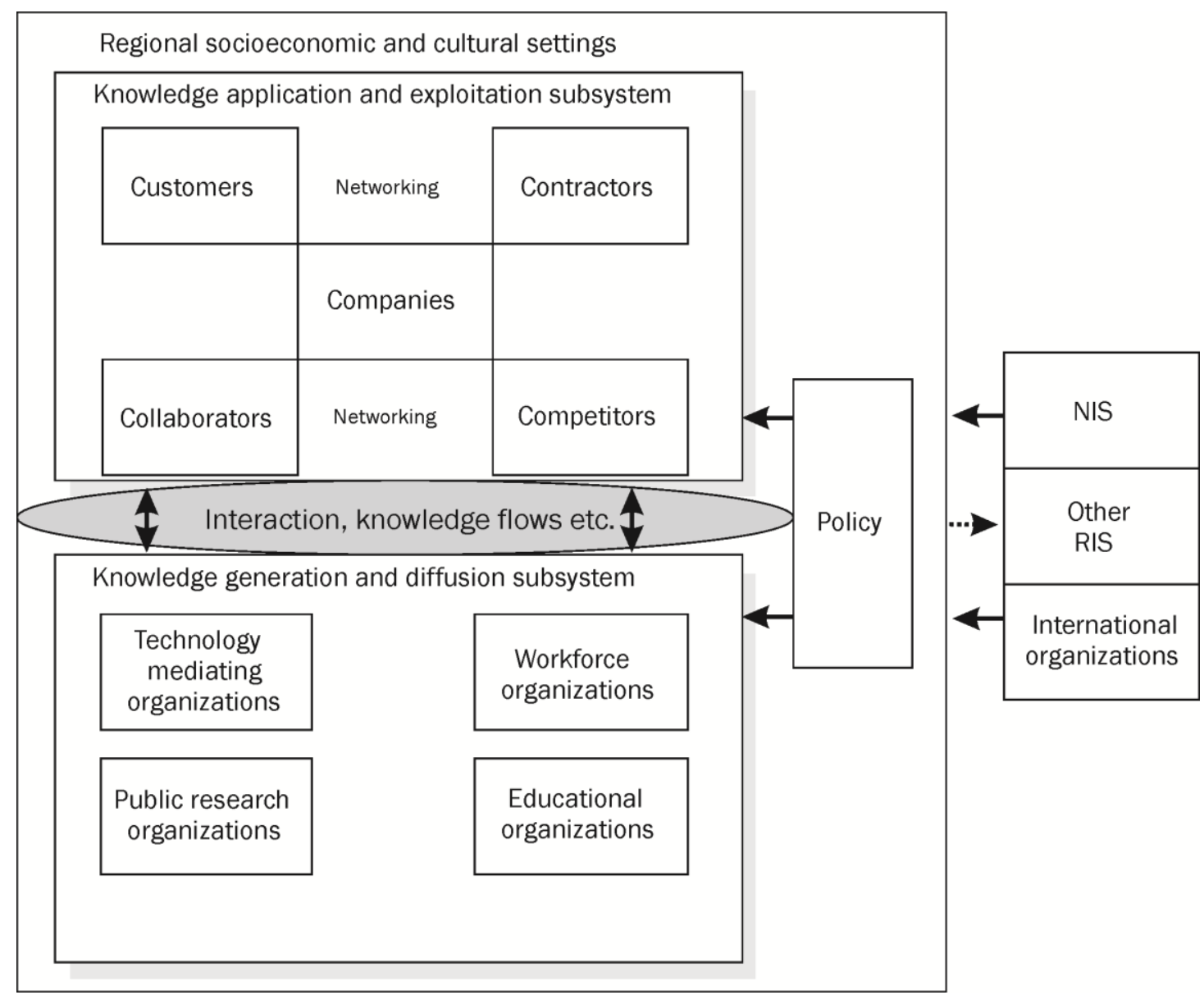

Figure 1 A schematic illustration of RIS [simplified from Autio (1998) and Tödtling and Trippl (2005)].

Universities can play a major role in the promotion of KBD in a region, as, according to previous literature, when the local engagement is successful, universities are important economic agents, useful generators of knowledge and key actors for regional economic and innovation performance (Benneworth et al., 2009; Coenen, 
2007; Graf and Henning, 2009). Entrepreneurial universities have even integrated economic development into the university as an academic function capitalising knowledge and establishing themselves as economic actors (Etzkowitz, 1998). However, the mere presence of a university in a region is not sufficient to stimulate innovations and strong regional economic growth: 'the flow of knowledge does drive innovation, but knowledge transfer from universities to industry is a fluid, complex and iterative process involving many different actors' [Bramwell and Wolfe (2008), p.1175]. As the role of the universities has evolved (Uyarra, 2010; Youtie and Shapira, 2008), the linear model from university research (e.g. in the form of science publications) to products commercialised by private companies, although an important part of U-I relationship (Lee, 1996; Mansfield, 1991), is too straightforward and narrow a way of looking at the possibilities of U-I collaboration. Furthermore, in U-I collaboration the exchange of knowledge manifests in both directions (MeyerKrahmer and Schmoch, 1998).

The universities are not just a source for knowledge spillovers (Anselin et al., 2000; Ponds et al., 2010), but also impact the local economy through knowledge transfer mechanisms such as joint R\&D projects and research collaboration, start-ups or spinoffs as well as education and training (e.g. D'Este and Patel, 2007; Landry et al., 2006). Thus the main emphasis on U-I collaboration should be on both, that is, how can universities create new knowledge and deploy it in an economically useful way (Bercovitz and Feldman, 2006). In this respect there is also a growing interest in the role of intermediaries as the facilitators of knowledge transfer from university to industry (e.g. Bramwell and Wolfe, 2008; Inkinen and Suorsa, 2010). 
In relation to U-I collaboration, probably the most evident ways in which knowledge transfer can be beneficial for (local) firms are joint R\&D project and research collaboration with universities; indeed, previous studies have empirically shown that private companies gain from research partnerships with and from the possibility to access knowledge generated by universities (e.g. Audretsch et al., 2005; Baba et al., 2009). Universities also foster new enterprises in the form of university spin-offs, firms directly linked to the universities, and university related start-ups, firms created by university graduates (Bathelt and Spigel, 2011; Pirnay et al., 2003), benefiting and improving the local economy through knowledge accumulation and numerous other ways (see Benneworth and Charles, 2005).

In previous studies it has been emphasized that the presence of educated (skilled, talented) human capital bolsters the innovative output of regions and creates greater economic activity (Florida, 2002; Glaeser, 2000). Universities are important in this equation as they both supply, through education and training, skilled graduates and attract knowledge workers (Audretsch et al., 2005; Lambooy, 2004). In fact Schartinger et al. (2001) have demonstrated with Austrian data that the main channel of knowledge transfer from universities to the private sector occurs through the mobility of highly skilled personnel, that is, through the employment of graduates and the mobility of university researchers into private firms.

In addition, locational factors are also significant: physical proximity still has not lost its relevance (Ala-Rämi and Inkinen, 2008; Kaufmann et al., 2003), generally leaving peripheral regions at a disadvantage (Copus et al., 2008). In special circumstances location does not necessarily hinder the KBD capacity of regions. The case in point is 
an institution-driven RIS (Doloreux and Dionne, 2008), which can act as an alternative strategy for peripheral regions promoting KBD: institutions can help to deal with organizational thinness, which is a major barrier for knowledge sharing and innovation in peripheral regions (Tödtling and Trippl, 2005; also Sotarauta and Kosonen, 2004). If this would be the case at a local university then one could speak of a university-driven RIS. Thus the lack of a dense geographical network, especially in sparsely populated regions, can be compensated by organizational proximity, as local educational and research institutes serve as an important knowledge source especially for small- and medium-sized enterprises (Virkkala, 2007).

\section{Regional context}

In Finland, regions (NUTS-3) and localities (LAU-1 and 2) do not have a formal role in the formulation of innovation and science policies as it is largely in the hands of the national government, but they can try to influence these national policies indirectly through local initiatives (Jauhiainen, 2008). As their policy instruments are limited, some researchers have questioned if, regions/localities in Finland can be considered 'proper' RISs (Sotarauta and Kautonen, 2007). There are local and regional intermediaries providing aid and funding in Finland, but most of the innovation related funding still derives from the national level (Inkinen and Suorsa, 2010). Thus the role of the Finnish public sector in regional innovative activities is more visible through universities, as Finnish universities work more closely with business and industry than they do in many other countries (Ebersberger, 2005; Husso, 2001). In fact, the very idea behind the regionalisation of university education and the establishment of provincial universities, including Joensuu in 1969, in Finland in the 1960s and 1970s was founded on the idea of spreading development across the nation 
to act as a locational incentive for firms (see Clark, 1998; Tervo, 2005). The growing importance of the third mission of the university (the universities' contribution to the society) and the role of these activities in the academic promotion procedures in Finland supports the active interaction from the university perspective.

Joensuu (population ca. 73,000; land area ca. 2,380 km²), situated in the province of North Karelia in Finland, has a long tradition in the forest industry. Forestry, also, has a prominent role in the faculty division of the UEF (see Clark, 1998). Nowadays other industry branches, technology industries in particular, are equally important in the industrial set-up of the region. Still, Joensuu, as most Finnish regions, is predominantly service-oriented and education, health care and other social services are the most important source for employment. Although, Joensuu is a provincial centre it is nonetheless situated in the eastern periphery of Finland, where its location is seen in terms of commuting time and distance to the more prominent population centres of Finland (e.g. to the capital of Helsinki).

The university sector is the main contributor to $R \& D$ activities in the region: the significance of university $R \& D$ is well above (reversed compared to) the national average (Figure 2). An example of the engagement of the university in the local economy is the Joensuu Science Park (JSP), linked closely to the UEF, which fosters start-ups and promotes regional enterprise and employment opportunities (also Clark 1998; Kakko and Inkinen, 2009; Vartiainen and Viiri, 2002). However, the reality is that compared to other Finnish universities the proportional entrepreneurial activity among UEF graduates is only modest (Lautanen and Saukkonen, 2010). Moreover, simply bringing firms together by building science parks is not enough to effectively 
stimulate the firms: there has to be sufficient real inter-firm linkages in the region (Knoben, 2009; Sadowski et al., 2003).

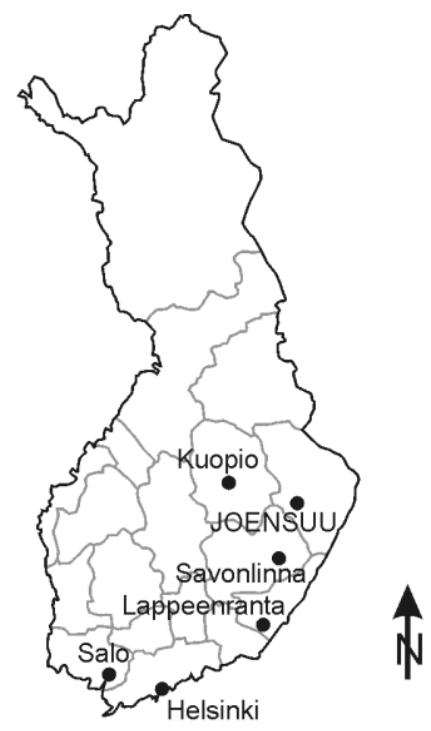

\begin{tabular}{llccc} 
& & Business sector & University sector & Public sector \\
\hline Finland & R\&D spendings & $71,4 \%$ & $18,9 \%$ & $9,7 \%$ \\
& R\&D pers onnel & $51,9 \%$ & $36,4 \%$ & $11,7 \%$ \\
\multirow{3}{*}{ Joensuu } & R\&D spendings & $24,3 \%$ & $55,6 \%$ & $20,0 \%$ \\
& R\&D personnel & $21,6 \%$ & $64,4 \%$ & $14,1 \%$
\end{tabular}

Figure 2 R\&D characteristics of Finland and Joensuu (Source: Statistics Finland, 2011).

\section{Thematic analysis framework}

The regional characteristics of the U-I collaboration are discussed here through knowledge transfer mechanisms. Thus drawing especially from Bercovitz and Feldman (2006) the interview framework and the analysis were divided into three themes (Table 1); the chosen technique for conducting the interviews was semistructured thematic interviews. The background for this framework is the aim to identify the influences of the legal, socio-economic, cultural and policy environments (comprising the innovation system) and the university specific factors, which determine the rate and type of university knowledge production and transfer. These 
determinants will give insight into the impacts of the university on the technological change (innovativeness) in a given region and to the role of the U-I collaboration and knowledge transfer in supporting KBD in that region.

Table 1 The interview framework [adapted from Bercovich and Feldman (2006)].

\begin{tabular}{ccc}
\hline & KNOWLEDGE TRANSFER MECHANISMS & \\
\hline $\begin{array}{c}\text { 1) Sponsored and } \\
\text { joint research }\end{array}$ & 2) Hiring of students and & 3) Spin-off and \\
availability of skilled workers & start-up firms
\end{tabular}

This paper focuses on the three themes in table 1, leaving aside two other forms of knowledge transfer introduced by Bercovich and Feldman (2006): licensing and serendipity (simple luck or chance). The legal institution concerning licensing (e.g. patents and trademarks) in Finland is more related to national than regional scale, whereas the role of serendipity, depicting the informal mechanisms and interaction between the university and industry, is hard and time consuming to study (Nilsson et al., 2010). The selection of the interviewed organisations was done according to figure 1 on the basis that they each represent a significant actor in RIS including the university [Joensuu is also the home for more working-life (cf. polytechnic or college), than science-, oriented North Karelia University of Applied Sciences (UAS), but in this study the main emphasis is on the UEF, campus of Joensuu], local intermediaries and business organisations as well as governmental and administrative organisations engaged in development and promotion of business life. These organizations represent the knowledge generation and diffusion subsystem. Also, representatives from the most notable 'local' firms [in terms of revenue and exportation value (see Kauppalehti, 2011)], representing the knowledge application and exploitation subsystem, were interviewed. The list of interviewees $(n=16)$ is presented in appendix 1. The list is not an exhaustive inclusion of all the regional 
actors, but rather a sample of important local organizations. The interviewees, each in a managerial role or in a development-related position in their home organization, are threaded anonymously. The following results and discussion are based on the conducted interviews aggregated and analysed according to the themes and groups of different organisation types presented in appendixes $1-2$.

\section{Knowledge transfer and university-industry collaboration in Joensuu}

\section{Sponsored and joint research}

From the basis of the conducted interviews, there are many examples of on- and longgoing sponsored and joint research projects between the university and industry in Joensuu. One example, brought up by the governmental and administrative organisations, of this collaboration is the SIB-labs of the UEF. SIB-labs was founded to promote technology transfer in the field of photonics and materials research and to support the research needs of industry. However, interviewees also underlined that the services of SIB-labs are relevant for only a small number of local firms. Thus, in view of the interviews, there is a lot of room for intensifying the collaboration in other industry sectors, as the potential of research relevant to industry is significant, but mostly unutilised. In fact, the interviewed firms expressed their interest in universityindustry collaboration if they would know in more detail, the extent to which the university could offer them interesting possibilities. Financial resources were not generally conceived as a problem, as there are sufficient national and regional funding bodies to turn to. Rather, as reported by the university sector, local businesses, especially small firms, are not necessarily well aware of the possibilities that the university could offer and, vice versa; indeed, there are still misconceptions among 
the personnel of the university regarding the nature of contracted research (cf. Laukkanen, 2003).

The only 'legal' constraints brought up are related to commissioned theses: as a general rule a thesis has to be public, whereas usually the companies would want the thesis to be classified for a period of time. Compromises, however, with some parts of the thesis being classified, are not uncommon. Still, intermediaries and business organisations expressed their concern that the publicity of university theses and research (on the whole) can hinder the possibilities of research collaboration, as firms need secrecy to maintain their competitive advantage. Regardless, according to firms, theses are one of the most common forms of U-I collaboration in the region.

According to the conducted interviews, most notably the problem related to U-I collaboration in research is between the local business environment and the research done in the university: there are evident mismatches between the research fields and the local industry. For example, there is no technical faculty on the Joensuu campus, and therefore many local firms report to be collaborating with the 'near-by' Lappeenranta University of Techonology as well as with universities of applied sciences. For some (e.g. computer-sciences-related) firms the university is an extremely important collaboration partner, but many of the firms and organisations representing the local businesses interviewed declared, however, a lack of university research relevant to their industry or to their company (or companies they represent). 
Hiring of students and availability of skilled workers

According to the official university statistics, about $20 \%$ of the graduates from the UEF lack the work experience from their own field when they graduate (UEF, 2011). Furthermore, according to the opinion of the interviewees, there are mismatches between the subject coverage taught at the university and the needs of the local business life. Also, the perception of intermediaries and business organisations is that university students are not well aware of where to find trainee positions and many local firms lack knowledge of what the trainees could offer them. The problem is quite similar when compared to research collaboration. In particular smaller firms might shun the hiring of university students and graduates due to preconceptions that are not based on experiences. However, the interviews brought up good examples of measures aiming to mitigate these problems, such as the Knot-project spearheaded by the North Karelia Chamber of Commerce, and of already well-functioning collaboration between the local firms and the university (especially in computer sciences). The aim of the Knot-project is to help international students and the local firms to find each other and at the same time to remove the need of an intermediating body so that in the future the university and industry side would be in direct contact with each other. Similarly, firms recruiting university graduates stated that they do exhibit themselves at the UEF to attract a future workforce.

The opinion of the interviewees is that, in relation to the availability of a skilled workforce, the situation is generally good in fields taught at the UEF, campus of Joensuu, which has even led to unemployment in some sectors. However, for some special branches an evident lack of skilled workers was reported. Additionally, in some fields (e.g. electronics) firms perceived the UAS as a more important local 
source for skilled workers and trainees. In relation to the locational factors of Joensuu, in the periphery, the flow of graduates and skilled workers between (away and from) different regions is considered natural by the university and governmental and administrative organisations. Especially firms expressed that the situation differs between the centre of Joensuu and its more peripheral parts, but the overall attraction of Joensuu as a place to work and live is considered at least fair. Actually, governmental and administrative organisations considered it an advantage for firms to be situated in Joensuu, where the educated workforce is likely to remain in the region and in the same workplace, at least more so than in larger cities. This is the case, according to the interviews, due to existing social ties and a smaller array of choice of employers. This 'loyalty' saves the firms from mandatory allocation of resources to the training and introductory procedures of new employees. However, the role of the Joensuu campus as a provincial university still means that many of the students return to their original domiciles after graduation.

\section{Spin-off and start-up firms}

There are not that many university spin-off or start-up firms in the region, but some positive examples have emerged especially in the fields of optoelectronics (cf. Clark, 1998), information technology and business studies. The JSP was seen as a good incubator of these firms, as many of the existing spin-offs or start-ups are located, or were founded, in the premises. Drawn from the interviews, the main reason for the sporadic emergence of university spin-offs and start-ups seems to be related to the lack of entrepreneurial spirit, as entrepreneurial activity is related to personal traits, among the researchers, graduates and students of the UEF. However, interviewees were aware of projects [e.g. the OSSI-project, a joint effort of the Aducate - Centre 
for Training and Development (UEF) and North Karelia Enterprise Agency] and business idea competitions, with promising results, to promote the establishment of new university spin-off firms and to encourage entrepreneurship among university students and graduates. Still, past experiences have shown that despite ample support from the JSP, Entrepreneurship and Innovation Services (UEF) and other regional actors, the road from a business idea and technical know-how to the actual success of a product or a service is difficult, as governmental and administrative organisations were aware of several failed university spin-off and start-up firms in the region.

The university's stand is that the faculty are allowed to work in private companies or found their own businesses alongside their work in the university as long as the firms' operations do not compete with the university (the decision is processed case by case). Although the view of the university on entrepreneurial activity has moved in a more favourable direction, this is not commonplace: according to the university representatives interviewed, some of the senior staff (professors etc.) work in private companies, but among the younger staff (researchers etc.) it is quite rare. Furthermore, intermediaries and business organisations considered differences in the way of thinking and in the working cultures between the university and private sector as a cause of difficulties for university staff wanting to work in local companies or establish their own businesses.

\section{Synthesis and discussion}

All in all there are good examples of how the knowledge transfer between university and industry can contribute to the KBD and innovation activity in Joensuu. However, according to the results there is still much work to be done at the Joensuu campus. 
The notion that universities serve other important functions besides U-I collaboration is acknowledged, but if the campus of Joensuu wants to be regarded as an entrepreneurial university and maximise the impacts that U-I collaboration can have on the KBD of the region the deficiencies in the 'capitalisation of knowledge' from teaching and research should be discussed.

A summary of the interviews and analysis is presented in table 2. There are common topics inside the themes between different groups of interviewed organisations. On the positive side there is a common striving towards a closer integration between business life and the university. This is implemented through different projects and intermediaries. Moreover, the aid and funding possibilities for U-I collaboration and a spin-off or start-up creation are ample. However, most evident similarities are found between the perceived mismatches (e.g. the problems related to divergent practices between university and business life are a cross-cutting theme). 
Table 2 The main results of the interviews according to the thematic framework and organisation types.

\begin{tabular}{|c|c|c|c|}
\hline & Sponsored and joint research & Hiring of students and graduates & Spin-off and start-up firms \\
\hline & FIRMS & FIRMS & FIRMS \\
\hline Good experiences & Thesis, computer sciences & Sufficient educated workforce & - \\
\hline Disadvantages & Lack of technical faculty & Peripherality & - \\
\hline \multirow[t]{2}{*}{ Mismatches } & Firms' needs vs. uni. research & Centre vs. outskirts & - \\
\hline & GOVERNMENTAL/ADMINISTRATIVE ORGANISATIONS & GOVERNMENTAL/ADMINISTRATIVE ORGANISATIONS & GOVERNMENTAL/ADMINISTRATIVE ORGANISATIONS \\
\hline Good experiences & SIB-labs, optoelectronics & Local worker immobility & Science Park \\
\hline Disadvantages & Lack of common operational environment & Lack of know-how in special branches & Lack of entrepreneurial spirit \\
\hline \multirow[t]{2}{*}{ Mismatches } & Business life needs vs. uni. research & Business life needs vs. uni. education & Technical vs. business know-how \\
\hline & INTERMEDIARIES AND BUSINESS ORGANISATIONS & INTERMEDIARIES AND BUSINESS ORGANISATIONS & INTERMEDIARIES AND BUSINESS ORGANISATIONS \\
\hline Good experiences & Aid and funding possibilities & Knot-project & OSSI-project, business idea competitions \\
\hline Disadvantages & Lack of technical faculty & Lack of know-how in special branches & Lack of courage and suitable attitude \\
\hline \multirow[t]{2}{*}{ Mismatches } & Business interests vs. research interests & Trainees' vs. firms' awareness & Uni. working culture vs. business working culture \\
\hline & UNIVERSITY & UNIVERSITY & UNIVERSITY \\
\hline Good experiences & Content and recurring partners & Out-of-town students who become inhabitants & Aid and funding possibilities, business studies \\
\hline Disadvantages & Lack of marketing & Problems of the provincial universities & Lack of sales know-how \\
\hline Mismatches & Large vs. small companies & Generic vs. special branches & New opportunities vs. rivalry \\
\hline
\end{tabular}


In Joensuu the university research and education does not cover for all the local business needs especially due to the lack of technical faculty (Table 2). The lack of applied industry-related research is common in science universities due to their role in conducting basic research, but still both the university and industry are encouraged to collaborate, as there might be interfaces that they do not (yet) realise. The university side should help firms to find the information they need in a more compact way, now that the information is dispersed in different bodies inside the university. A centralised contact person (or a `service desk'), directly concerned with the promotion of U-I collaboration, with a service attitude is needed. Even more so a sales-oriented contact person from the university could actually actively inform the local business of new research collaboration possibilities. This would help the firms to acquire the necessary courage to collaborate.

In relation to the hiring of graduates, the mismatches are between the local business life sector and the university's subject coverage. In general, there is a sufficient supply of skilled workers and graduates, but not for special branches (Table 2). Some of the fields produce graduates of which all are not meant to be employed locally (e.g. teachers), that is to say, the mission given to the UEF is not to cater solely for (all) the local needs. Thus the situation is especially good in fields related to the public sector, if a broader picture than strictly industry-related workplaces is taken into account. This is relevant as the local structure of employment is largely public-sector oriented. There are also substantial variations between different subjects in relation to the hiring of students: for some subjects practical work-training is mandatory and the training places are provided for by the university, but for other fields the situation is not that good. In fields benefiting the local business life, it is advisable to strengthen the U-I 
collaboration in this field (cf. Puhakka et al., 2010). Examples could be sought from the local UAS, as there the link with working life is already strong. The university could further encourage students to take into account the importance of working experience or impose working as a mandatory part of the curriculum when appropriate. The industry should take an active part in this by exhibiting their company to and by offering more training places for these prospective new employees.

In spin-off and start-up creation the problems have to do with personal traits, for example the lack of courage, know-how or an entrepreneurial spirit (Table 2). Hence, the entrepreneurial activity of the graduates (and university staff) in Joensuu, but also in other Finnish universities, was considered low. However, this is not solely an issue related to the university sector, as Finland performs low in country-wide comparisons on entrepreneurship (e.g. Bosma and Levie, 2010). Nevertheless, it is obvious that there should be a closer integration of entrepreneurship into the university teaching, as well as staff with entrepreneurial and private sector experience to promote and encourage entrepreneurship and industry collaboration. Without significant changes in the Finnish university system ('tenure tracking'), the integration of industry and private-sector experience and an academic career is hard, as many of the positions at the university are appointed almost solely on the basis of academic success. Therefore, the necessary experience could be (and to some extent already is) also acquired directly from the private sector as guest lecturers. For example, the North Karelia Chamber of Commerce maintains an online database of firms interested in sharing their views on entrepreneurship. 
The issue of serendipity was also bought up in the interviews: it seems that there are an abundance of different forums for a more informal U-I interaction in the region including the revival of alumni activities, social evenings, development groups and a variety of seminars and conferences. Furthermore, in JSP the university (the School of Computing) and firms co-locate enabling daily interaction between the university and industry. Serendipity could also be counted, in a way, as a potential asset for smaller localities, as the probability of informal interaction in a limited population is high (also the ease of formal collaboration between different organisations in smaller towns was considered as an asset compared to the situation in larger cities). It was also stressed by the interviewees that the U-I interaction need not be only local. While local links are extremely valuable in many ways, and it demands less 'effort' and resources to arrange and sustain them, the national and global connections are also equally important for both the business and the university sides, especially when concerning know-how in special fields not present on the local campus. Still, though the logistical position of a firm does not place restrictions on networking with the university sector, the physical proximity is considered an asset.

\section{Conclusions}

This paper has addressed the issue of university driven RIS and KBD in peripheral settings. The RIS approach was used as a background to define the different actors contributing to the regional knowledge creation and application processes. The main interest was placed on the interaction between these actors, that is, the knowledge transfer mechanisms especially in the form of U-I collaboration. To partially fill in a gap in the literature, Joensuu was used as an example of a peripheral university town, as more often the research is conducted from the point of view of well-known 
universities and well-off regions. The conducted interviews point out that there are encouraging experiences of successful U-I collaboration, but also a lot of room for improvement to maximise the impact that the university could have on the innovativeness of local firms and on the regional economy. The main concerns deal with the lack of entrepreneurial spirit among the graduates and the partial mismatches between the local business life and university research and teaching. The lack of entrepreneurial striving is a specific problem for Finland, but in particular amongst the graduates and faculty of the UEF. The firms and the university are encouraged to collaborate to find common interfaces, as the problems concerned with U-I collaboration, particularly joint research and the hiring of students and graduates, are not solely on the university side. Whereas the university has to improve its services for firms, more active private sector participation is also needed. Similarly, entrepreneurship is recommended to be more tensely incorporated in the curriculum of the university with the help of guest lecturers from local businesses. As a regionspecific conclusion it can be stated that, when compared to larger urban regions the peripheral location of Joensuu does impose limitations to the availability of skilled workers at hand, but the negative impact is compensated for by employee loyalty to their employers, due to existing social ties and thinner possibilities for other employment.

The question of whether the Joensuu-based RIS can be considered as universitydriven is manifold. On the other hand the, campus offers many opportunities for firms in the region, but then it seems that these opportunities are not realised, to a significant degree, in the form of U-I collaboration: in relation to the university, the organisational proximity supporting local firms, discussed by Virkkala (2007), is not 
evident in the region. Of course, the university serves an important role in the KBD, but according to the interviewees the university will need to liaise more closely with regional business life, in order to effectively alleviate the difficulties faced by peripheral regions in the KBD.

Although the empirical material was confined to a single peripheral university town, and the conclusions drawn are therefore case-specific, the discussion offered here has broader applications for the university sector as a whole and in particular to other peripheral regions, to strengthen the knowledge transfer mechanisms between the university and industry. Still, it has to be noted that the interviews carried out include only the opinions of a limited number of regional actors. Thus an obvious next step for research would be to conduct a larger-scale study or a survey to take into account the views of a larger set of companies, preferably small- and medium-sized enterprises as they could benefit relatively more from university linkages, but at the same time might lack the resources to collaborate, as compared to their larger counterparts. Also, comparative research on the role of the Finnish universities of applied sciences is needed. Similarly, the role of serendipity in the knowledge transfer flows would be an interesting avenue for further research, as already the preliminary notions in this study confirm that there are an abundance of informal relations between the university and industry in the case region. This informal interaction is more than likely to make its own contribution to the overall performance of the region's KBD efforts. 


\section{Acknowledgments}

The author would like to express his gratitude to the editor of this special issue and the anonymous reviewers for their comments improving the paper. The author also thanks Mr Arttu Paarlahti for his help with the figures and the interviewees for their time and effort. This work is a part of the project 127213 funded by the Academy of Finland.

\section{References}

Ahlqvist, T. and Inkinen, T. (2007) 'Technology foresight in scalar innovation systems: a spatiotemporal process perspective', Fennia - International Journal of Geography, Vol. 185, No. 1, pp.3-14.

Ala-Rämi, K. and Inkinen, T. (2008) 'Information technology, communication and networking in software companies of northern Finland', International Journal of Knowledge Management Studies, Vol. 2, No. 3, pp.320-334.

Anselin, L., Varga, A. and Acs, Z. (2000) 'Geographical spillovers and university research: a spatial econometric perspective', Growth and Change, Vol. 31, pp.501-515.

Aronson, J. (1994) 'A pragmatic view of thematic analysis', The Qualitative Report, Vol. 2, No. 1.

Asheim, B. and Coenen, L. (2005) 'Knowledge bases and regional innovation systems: comparing Nordic clusters', Research Policy, Vol. 34, pp.1173-1190.

Asheim, B. and Gertler, M. (2005) 'The geography of innovation: regional innovation systems', in: Fagerberg, J., Mowery, D. and Nelson, R. (Eds.), The Oxford Handbook of Innovation, pp.291-317, Oxford University Press, Oxford.

Audretsch, D., Lehmann, E. and Warning, S. (2005) 'University spillovers and new firm location', Research Policy, Vol. 34, pp.1113-1122.

Autio, E. (1998) 'Evaluation of RTD in regional systems of innovation', European Planning Studies, Vol. 6, No. 2, pp.131-140. 
Baba, Y., Shichijo, N. and Sedita, S.R. (2009) 'How do collaborations with universities affect firms' innovative performance? The role of "Pasteur scientists" in the advanced materials field', Research Policy, Vol. 38, pp.756-764.

Bathelt, H. and Spigel, B. (2011) 'University spin-offs, entrepreneurial environment and startup policy: the cases of Waterloo and Toronto (Ontario) and Columbus (Ohio)', International Journal of Knowledge-Based Development, Vol. 2, No. 2, pp.202-219.

Benneworth, P. (2007) 'Seven samurai opening up the ivory tower? The construction of Newcastle as an entrepreneurial university', European Planning Studies, Vol. 15, No. 4, pp.487-509.

Benneworth, P. and Charles, D. (2005) 'University spin-off policies and economic development in less successful regions: learning from two decades of policy practice', European Planning Studies, Vol. 13, No. 4, pp.537-557.

Benneworth, P., Coenen, L., Moodysson, J. and Asheim, B. (2009) 'Exploring the multiple roles of Lund University in strengthening Scania's regional innovation system: towards institutional learning', European Planning Studies, Vol. 17, No. 11, pp.1645-1664.

Bercovitz, J. and Feldman, M. (2006) 'Entrepreneurial universities and technology transfer: a conceptual framework for understanding knowledge-based development', Journal of Technology Transfer, Vol. 31, pp.175-188.

Bosma, N. and Levie, J. (2010) Global Entrepreneurship Monitor. 2009 Global Report, Global Entrepreneurship Research Association.

Bramwell, A. and Wolfe, D. (2008) 'Universities and regional economic development: the entrepreneurial university of Waterloo', Research Policy, Vol. 37, pp.1175-1187.

Carrillo, F. J. (2009) 'Demarcation and levels of analysis in knowledge based development', Journal of Knowledge Management, Vol. 13, No. 5, pp.208-213.

Clark, B. (1998) Creating Entrepreneurial Universities: Organizational Pathways of Transformation, Pergamon Press, New York. 
Coenen, L. (2007) 'The role of universities in the regional innovation systems of the North East England and Scania, Sweden: providing missing links', Environment and Planning $C$, Vol. 25, pp.803-821.

Cooke, P. (1992) 'Regional innovation systems: competitive regulation in the new Europe', Geoforum, Vol. 23, No. 3, pp.365-382.

Copus, A., Skuras, D. and Tsegenidi, K. (2008) 'Innovation and peripherality: an empirical comparative study of SMEs in six European Union member countries', Economic Geography, Vol. 84, No. 1, pp.51-82.

D'Este, P. and Patel, P. (2007) 'University-industry linkages in the UK: what are the factors underlying the variety of interactions with industry?', Research Policy, Vol. 36, pp.12951313.

Doloreux, D. and Dionne, S. (2008) 'Is regional innovation systems development possible in peripheral regions? Some evidence from the case of La Pocatière, Canada', Entrepreneurship \& Regional Development, Vol. 20, No. 3, pp.259-283.

Doloreux, D. and Parto, S. (2005) 'Regional innovation systems: current discourse and unresolved issues', Technology in Society, Vol. 27, pp.133-153.

Ebersberger, B. (2005) The Impact of Public R\&D Funding, VTT, Espoo.

Etzkowitz, H. (1998) 'The norms of entrepreneurial science: cognitive effects of the new university-industry linkages', Research Policy, Vol. 27, pp.823-833.

Etzkowitz, H. and Leydesdorff, L. (2000) 'The dynamics of innovation: from national systems and "Mode 2" to a Triple Helix of university-industry-government relations', Research Policy, Vol. 29, pp.109-123.

Florida, R. (2002) 'The economic geography of talent', Annals of the Association of American Geographers, Vol. 92, No. 4, pp.743-755.

Franz, P. (2011) 'Editorial: attempts to bring knowledge, universities and spatial development together', International Journal of Knowledge-Based Development, Vol. 2, No. 2, pp.129131. 
Glaeser, E. (2000) 'The new economics of urban and regional growth', in: Clark, G., Feldman, M. and Gertler, M. (Eds.), The Oxford Handbook of Economic Geography, pp.83-98, Oxford University Press, Oxford.

Graf, H. and Henning, T. (2009) 'Public research in regional networks of innovators: a comparative study of four East German regions', Regional Studies, Vol. 43, No. 10, pp.1349-1368.

Husso, K. (2001) 'Universities and scientific research in the context of the national innovation system of Finland', Fennia - International Journal of Geography, Vol. 179, No. 1, pp.2754.

Inkinen, T. and Suorsa, K. (2010) 'Intermediaries in regional innovation systems: hightechnology enterprise survey from Northern Finland', European Planning Studies, Vol. 18, No. 2, pp.169-187.

Jauhiainen, J. (2008) 'Regional and innovation policies in Finland - towards convergence and/or mismatch?', Regional Studies, Vol. 42, No. 7, pp.1031-1045.

Kakko, I. and Inkinen, S. (2009) 'Homo creativus: creativity and serendipity management in third generation science and technology parks', Science and Public Policy, Vol. 36, No. 7, pp.537-548.

Kaufmann, A., Lehner, P. and Tödtling, F. (2003) 'Effects of the internet on spatial structure of innovation networks', Information Economics and Policy, Vol. 15, pp.402-424.

Kauppalehti (2011) 'Yritykset - menestyjät', available at: http://www.kauppalehti.fi/5/i/yritykset/menestyjat, accessed on 16/08/2011.

Knoben, J. (2009) 'Localized inter-organizational linkages, agglomeration effects, and the innovative performance of firms', Annals of Regional Science, Vol. 43, pp.757-779.

Lambooy, J. (2004) 'The transmission of knowledge, emerging networks, and the role of universities: an evolutionary approach', European Planning Studies, Vol. 12, No. 5, pp.643-657. 
Landry, R., Amara, N. and Rherrad, I. (2006) 'Why are some university researchers more likely to create spin-offs than others? Evidence from Canadian universities', Research Policy, Vol. 35, pp.1599-1615.

Laukkanen, M. (2003) 'Exploring academic entrepreneurship: drivers and tensions of university-based business', Journal of Small Business and Enterprise Development, Vol. 10, No. 4, pp.372-382.

Lautanen, T. and Saukkonen, P. (2010) 'Yliopistolähtöinen yritystoiminta ja sen haasteet Pohjois-Karjalassa', SPATIA raportteja, Vol. 2010, No. 4.

Lee, Y. (1996) 'Technology transfer' and the research university: a search for the boundaries of university-industry collaboration', Research Policy, Vol. 25, pp.843-863.

Lundvall, B-Å. (1992) 'Introduction', in: Lundvall, B-Å. (Ed.), National Systems of Innovation: Towards a Theory of Innovation and Interactive Learning, pp.1-19, Pinter, London.

Mansfield, E. (1991) 'Academic research and industrial innovation', Research Policy, Vol. 20, pp.1-12.

Meyer-Krahmer, F. and Schmoch, U. (1998) 'Science-based technologies: university-industry interaction in four fields', Research Policy, Vol. 27, pp.835-851.

Mukkala, K. (2010) 'The role of regional policies in promoting networking and innovative activity: evidence from small Finnish high-tech firms', European Planning Studies, Vol. 18, No. 7, pp.1057-1076.

Nilsson, A., Rickne, A. and Bengtsson, L. (2010) 'Transfer of academic research: uncovering the grey zone', Journal of Technology Transfer, Vol. 35, pp.617-636.

Niosi, J. (2006) 'Introduction to the symposium: universities as a source of commercial technology', Journal of Technology Transfer, Vol. 31, pp.399-402.

Parrilli, M.D., Aranguren, M.J. and Larrea, M. (2010) 'The role of interactive learning to close the "innovation gap" in SME-based local economies: a furniture cluster in the Basque Country and its key policy implications', European Planning Studies, Vol. 18, No. 3, pp.351-370. 
Pirnay, F., Surlemont, B. and Nlemvo, F. (2003) 'Towards a typology of university spin-offs', Small Business Economics, Vol. 21, pp.355-369.

Ponds, R., van Oort, F. and Frenken, K. (2010) 'Innovation, spillovers and university-industry collaboration: an extended knowledge production function approach', Journal of Economic Geography, Vol. 10, pp.231-255.

Puhakka, A., Rautopuro, J. and Tuominen, V. (2010) 'Employability and Finnish university graduates', European Educational Research Journal, Vol. 9, No. 1, pp.45-55.

Sadowski, B.M., Dittrich, K. and Duysters, G.M. (2003) 'Collaborative strategies in the event of technological discontinuities: the case of Nokia in the mobile telecommunication industry', Small Business Economics, Vol. 21, pp.173-186.

Schartinger, D., Schibany, A. and Gassler, H. (2001) 'Interactive relations between universities and firms: empirical evidence for Austria', Journal of Technology Transfer, Vol. 26, pp.255-268.

Schiuma, G. and Lerro, A. (2010) 'Knowledge-based dynamics of regional development: the intellectual capital innovation capacity model', International Journal of Knowledge-Based Development, Vol. 1, No. 1/2, pp.39-52.

Sotarauta, M. and Kautonen, M. (2007) 'Co-evolution of the Finnish national and local innovation and science arenas: towards a dynamic understanding of multi-level governance', Regional Studies, Vol. 41, No. 8, pp.1085-1098.

Sotarauta, M. and Kosonen, K-J. (2004) 'Strategic adaptation to the knowledge economy in less favoured regions: a South Ostrobothnian university network as a case in point', in: Cooke, P. and Piccaluga, A. (eds.), Regional Economies as Knowledge Laboratories, pp.1-19, Edward Elgar Publishing, Cheltenham.

Statistics Finland (2011) 'Statistical databases', available at: http://www.stat.fi/tup/tilastotietokannat/index_en.html, accessed on 07/06/2011.

Tervo, H. (2005) 'Regional policy lessons from Finland', in: Felsenstein, D. and Portnov, B. (Eds.), Regional Disparities in Small Countries, pp.267-282, Springer-Verlag, Berlin. 
Tödtling, F. and Trippl, M. (2005) 'One size fits all? Towards a differentiated regional innovation policy approach', Research Policy, Vol. 34, pp.1203-1219.

UEF - University of Eastern Finland (2011) 'Valmistuneiden sijoittuminen työelämään', available at: http://www.uef.fi/opiskelu/valmistuneidensijoittuminen, accessed on 09/09/2011.

Uyarra, E. (2010) 'Conceptualizing the regional roles of universities, implications and contradictions', European Planning Studies, Vol. 18, No. 8, pp. 1227-1246.

Vartiainen, P. and Viiri, A. (2002) 'Universities and their local partners: the case of the University of Joensuu, Finland', Industry \& Higher Education, Vol. 16, pp.83-89.

Virkkala, S. (2007) 'Innovation and networking in peripheral areas - a case study of emergence and change in rural manufacturing', European Planning Studies, Vol. 15, No. 4, pp.511-529.

Youtie, J. and Shapira, P. (2008) 'Building an innovation hub: a case study of the transformation of university roles in regional technological and economic development', Research Policy, Vol. 37, pp.1188-1204. 


\section{Appendix 1}

Interviews

GROUPS:

GROUPS:

Firms

Governmental

and administrative

organisations

Intermediaries

and business

organisations

University
ORGANISATION:

Abloy Ltd

Blancco Ltd

Cobham Mastsystem IntI Ltd

livari Mononen Ltd

Ouneva Ltd

Centre for Economic Development, Transport and the Environment for North Karelia

City of Joensuu

Regional Council of North Karelia

Joensuu Regional Development Company, Josek Ltd

Joensuu Science Park Ltd

North Karelia Chamber of Commerce

North Karelia Enterprise Agency

Regional Organisation of Enterprises in North Karelia

UEF, Campus of Joensuu, Aducate - Centre for Training and Development

UEF, Campus of Joensuu, Entrepreneurship and Innovation Services

UEF, Campus of Joensuu, Student Services
POSITION:

Product Manager

Chief Operating Officer

Managing Director

Managing Director

$R \& D$, Design Manager

Finance and Strategy Director

Spatial Planning Officer

Manager, Business Consultation Services

Development Director

Managing Director

Business Development Advisor

Managing Director

Coordinator

Business Development Advisor

Manager 


\section{Appendix 2}

Main themes of the interviews adapted from Bercovich and Feldman (2006)

1) Sponsored and joint research:

a) Is there a sufficient supply of university research relevant to industry in the region?

b) Are there economic incentives to finance university R\&D?

c) Are there antitrust provisions that limit company involvement in research consortia?

d) The potential, importance and depth of university-industry cooperation in the region?

e) The role of local U-I cooperation in relation to national or global cooperation?

2) Hiring of students and availability of skilled workers:

a) Is there a sufficient supply of students (and graduates) in the region?

b) Are there sufficient numbers of skilled workers in the region?

c) Are there screening mechanisms at work in recruiting?

d) The influence of locational factors (periphery as a hindrance vs. asset) for recruiting?

3) Spin-off and start-up firms:

a) Are faculty permitted to work outside the university?

- How common is this?

- Is it encouraged?

b) Are there special provisions to facilitate spin-offs (assistance, economic incentives etc.)? 